\title{
FROM THE BASICS OF SPATIAL CONSTRUCTIONS TO CONSTRUCTION OF AN IMAGE (a case study of engravings by Giovanni Battista Piranesi)
}

\author{
Elena Chernaya \\ Saint Petersburg State University of Architecture and Civil Engineering, \\ Vtoraja Krasnoarmejskaja ul. 4, St. Petersburg, 190005, Russia \\ elena.chernaya.75@mail.ru
}

\begin{abstract}
The article deals with the exhibition "Piranesi. Before and After. Italy-Russia. XVIII-XXI Centuries" held at the Pushkin State Museum of Fine Arts in Moscow in autumn, 2016. The exhibition revealed a new scientific interest to the creative heritage of the architect.

The author of the article visited the exhibition. During the analysis of the exposition, she discovered a justification of the hypothesis on existence of a common visual language in architectural graphics of G. B. Piranesi. Through the case study of the series "Antique Vases, Candelabra, Tombstones, Tomb-Chests, Trivets, Braziers, and Ancient Carvings..." the author examines the hornbook of "spatial constructions" of the artist.

Piranesi creatively interpreted techniques of Andrea Palladio's architectural graphics and introduced in them a "plasticity approach" peculiar for the art of theatrical scenery of his teacher Giuseppe Valeriani. He created a system of contrasting structural arrangements where angular and front perspectives appeared to be alignment elements, visually connecting different sketch sheets of the series. Following this approach, a geometric arrangement of his engravings acquired new features different from those used in the Andrea Palladio's "orthogonal approach" and form arrangement with the help of drawings and perspective geometry used by his contemporaries.

Multi-dimensional and multi-layered graphics is a composition technique typical of his engravings of other series, such as "Raccolta di varie vedute di Roma si antic ache moderna, intagliate la maggior parte dal celebre Giambattista Piranesi e da altri incisori" ("Collection of various views of Rome ancient and modern...") (1752). The synthesis of "linear" and "plastic" approaches in arrangement of a composition, when different principles prevail at certain stages is one of the factors affecting formation of individual visualization in his work. To illustrate this fact, we looked at compositional sketches of his predecessors, like G. Valeriani and M. Ricci. Using the example of one of the engravings by Piranesi (series "Carceri" ("Prisons")) we will show the process of forming the plastic composition.

In the process of compositional analysis of sketch sheets of the series "Antique Vases, Candelabra, Tombstones, Tomb-Chests, Trivets, Braziers, and Ancient Carvings...", we for the first time proposed mechanisms for determining the compositional center in the "three-dimensional" system of G. B. Piranesi's architectural graphics.
\end{abstract}

\section{Keywords}

Language of architectural graphics, composition, angular perspective, spatial constructions, drawing, orthogonal projections, geometric structure, image

\section{Introduction}

During 20 September and 13 November 2016, the exhibition "Piranesi. Before and After. ItalyRussia. XVIII-XXI Centuries" was held at the Pushkin State Museum of Fine Arts in Moscow.
This exhibition project hada great international resonance; supervisors of the exhibition were:

- Art and architecture historian Federica Rossi known as the author of numerous works devoted to architecture and artistic culture of Russia and 
Italy; a representative of the German Institute of Art History in Florence. Since 2012, she has been a visiting professor at the department of art and architecture history at the Moscow Architectural Institute (MArchl).

- Semen Mikhailovsky, the rector of the I. Repin St. Petersburg State Academy Institute of Painting, Sculpture and Architecture at the present time. Professor Emeritus of the Moscow Architectural Institute.

- Marina Mayskaya, a leading researcher and a supervisor of the Graphics department at the Pushkin State Museum of Fine Arts, a specialist on Italian drawing of $\mathrm{XV}-\mathrm{XX}$ centuries, an author of a three-volume catalogue-raisonne on Italian drawings from the collection of the Pushkin State Museum, as well as an author of numerous books and articles on the art of drawing.

The exhibition was located in five halls and on the walls of the Main Staircase. Three permanent exhibition halls No. 30,19 and 20 and two temporary halls No. 18 (previously used for Spanish and Italian art of the XVIII century) and No. 21 (French art of the XVII century) were allocated for the exposition (Figure 1).

Supervisors of the exhibition Federica Rossi, Semen Mikhailovsky, Marina Mayskaya, and Yuliya Merenkova included objects from the collection of casts made from antiques exhibited in the Pushkin State Museum of Fine Arts in Moscow into the exposition: plaster and bronze coated casts, electrotype copies of household items found during archeological excavations at Pompeii and Herculaneum. Cork models from the collection of the Russian Academy of Fine Arts Museum (Pantheon, Piramide Cestia, etc.) decorate the exposition (Figure 2).

As a part of the exhibition project, various meetings for adults and children are held in the museum halls and the lecture class (Prince Golitsyn Family Estate a

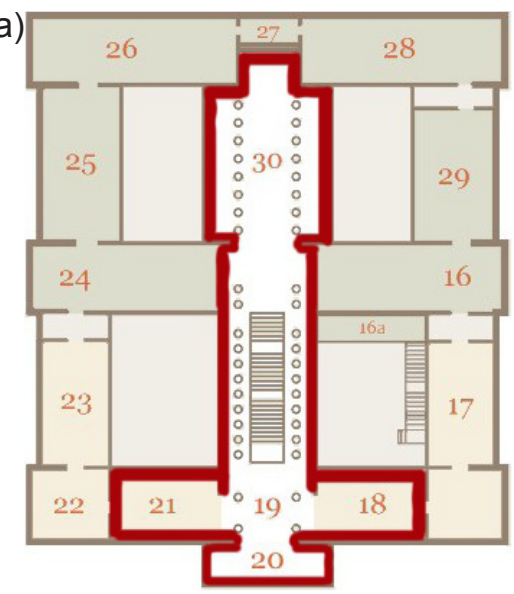

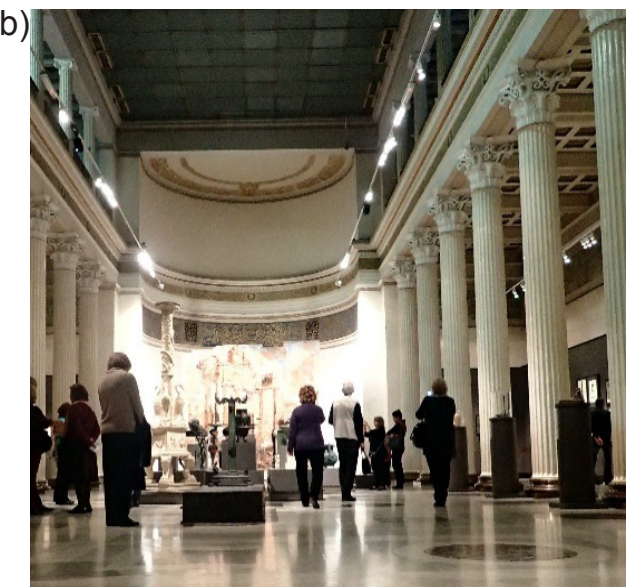

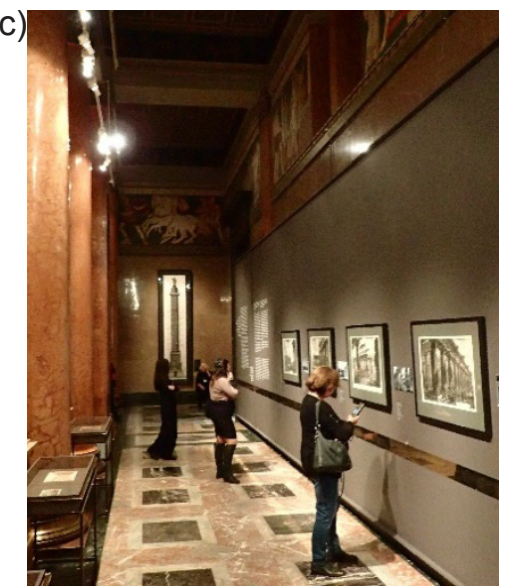

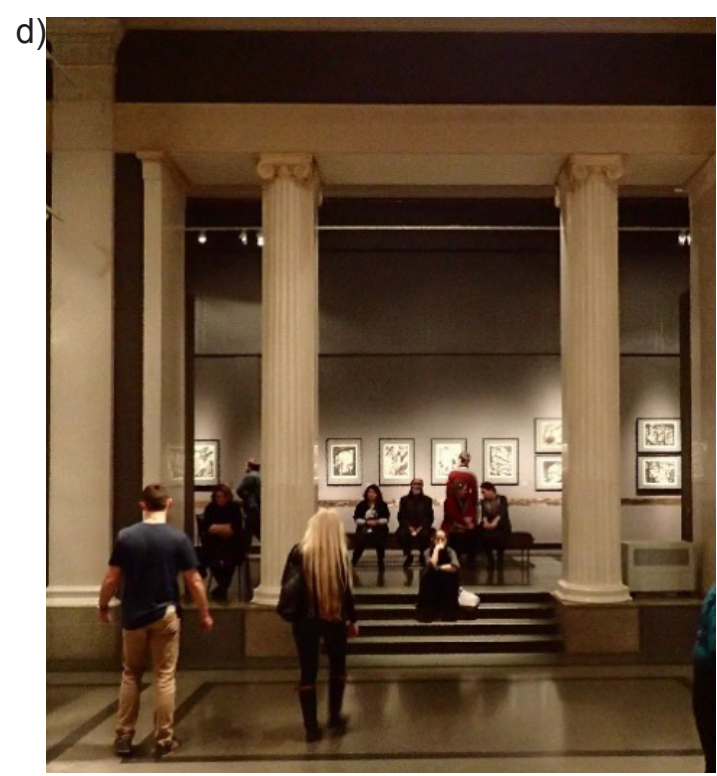

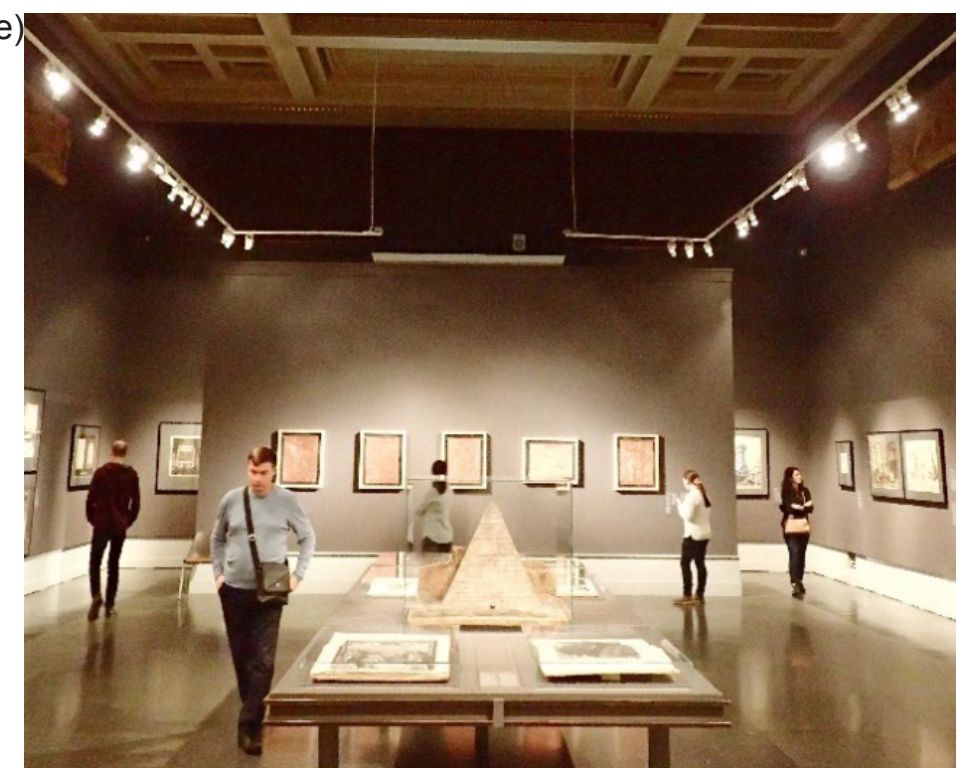

Figure 1. "Piranesi. Before and After. Italy-Russia. XVIII-XXI Centuries". Photos by E.A. Chernaya. Interiors of the Pushkin State Museum of Fine Arts where the exhibition took place: a) second floor plan of the Pushkin State Museum of Fine Arts (highlighted in red); b) exhibition hall No. 30; c) Main Staircase; d) exhibition hall No. 20; e) hall No. 18 
a)

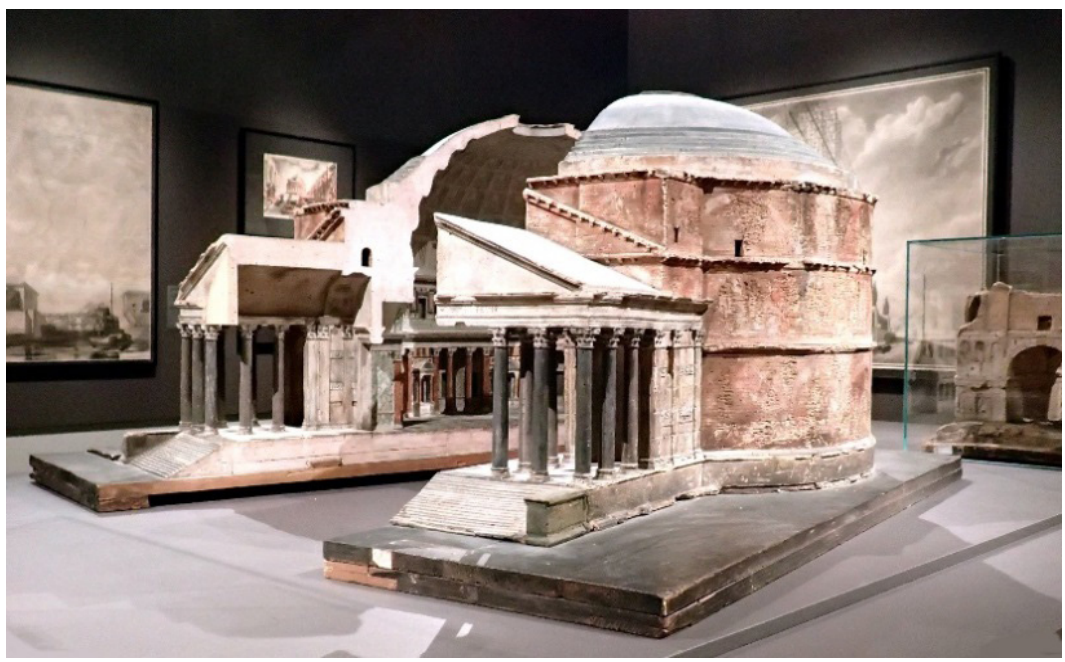

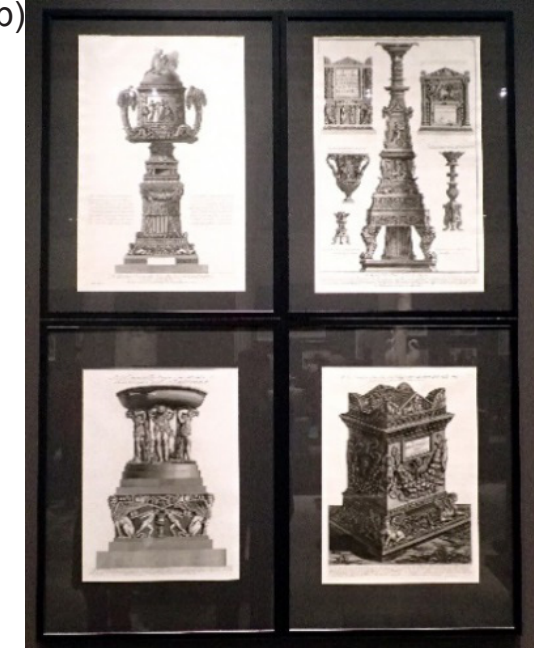

c)

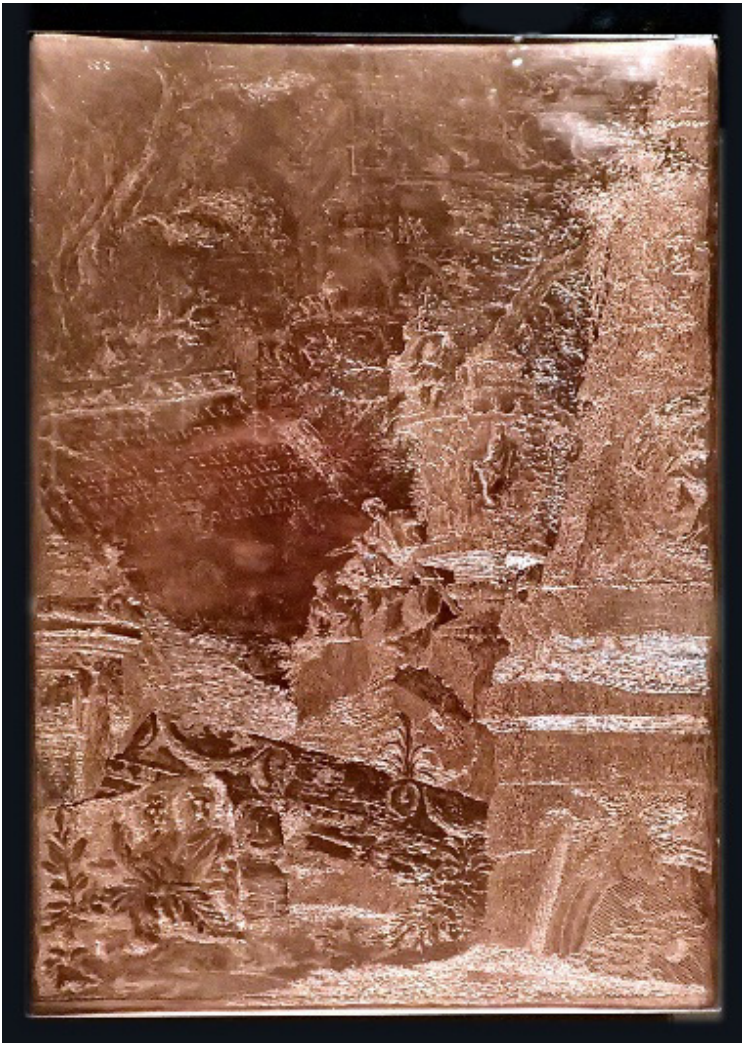

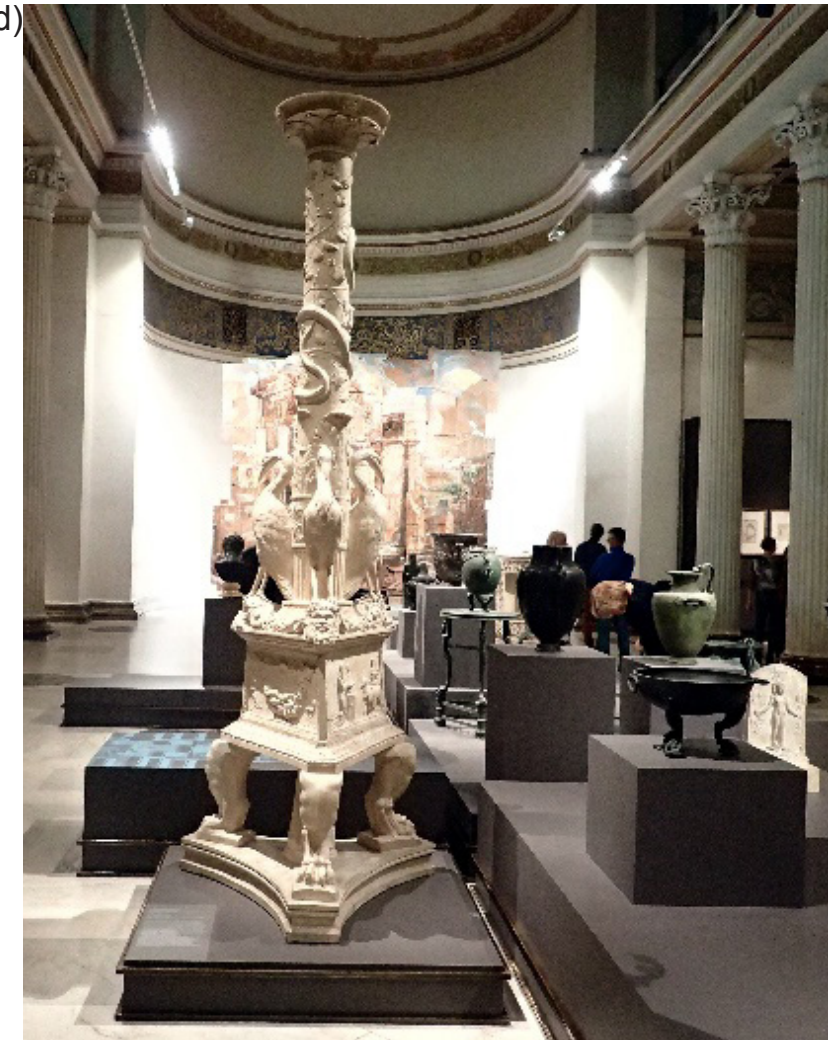

Figure 2. "Piranesi. Before and After. Italy-Russia. XVIII-XXI Centuries". Photos by E.A. Chernaya. Exposition of the exhibition: a) architectural model of the Pantheon; b) engravings of G. B. Piranesi and his assistants F. Piranesi, Brenna, and graphics of European, Russian, Soviet architects; c) a copper plate engraved by G. B. Piranesi; d) candelabrum with storks (tinted plaster, casting from a model. Original work: XVIII century marble)

located near the main building of the museum); at the meetings they reveal the phenomenon of architectural graphics of G. B. Piranesi and the role of his graphic heritage in the artistic culture of the following centuries until the second half of the XX century.

A fundamental catalogue was issued in the Pushkin State Museum of Fine Arts; it included articles by leading Russian (Marina Mayskaya, Dmitry Shvidkovsky, Semen Mikhailovsky, Nikolay Molok) and West-European researchers (Federica
Rossi, Maurizio Calvesi, Letizia Tedeschi, Ginevra Mariani et al.). The articles disclosed the following topics of the exhibition:

1. From theatrical scenery to the series "Carceri".

2. From "Collection of monuments of the Eternal City" to the series "Paestum".

3. Piranesi and study of the ancient heritage.

4. Piranesi. Ancientry as a source of inspiration.

5. Piranesi and Russian architecture of the XVIII century.

6. Piranesi and Soviet architecture. 
Such a variety of topics for scientific research of the artistic heritage of G. B. Piranesi evidences both of tradition and novelty of graphical language, which we try to reveal in this article.

\section{Methods and Materials}

Piranesi's graphical artistic culture formed during studying and working with famous masters of various directions of plastic arts, who influenced his compositional thinking, which manifested in geometric arrangement of his works. In this article we analyzed some sheets of the series "Antique Vases, Candelabra, Tombstones, Tomb-Chests, Trivets, Braziers, and Ancient Carvings..." where the architect sought to convey spatial representation of the shape in the plane to the viewer. He recreated whole ancient antiquities on his engravings taking only their fragments as the basis.

Our study focuses on the analysis of arrangement of geometrical and plastic structures in Piranesi's works.

The sketches clearly reveal professional nature of the artist's drawings. Piranesi's sketches constitute a rather small group of the exposition. They are valuable because they assert a main "driving idea" (the term by Yu. I. Kurbatov) of the author that clears up everything unnecessary, facilitating alignment of the image in the mind of the artist followed by arrangement of a hierarchical structure and the elements of the composition in the plane in the course of his artistic work. Then, the idea solidifies and gets its material embodiment in the process of a continuous work on a compositional sketch in the plane or on an architectural project.

Since the exhibition presented some sketches of scene painters (Giuseppe Galli Bibiena, Giuseppe Valeriani, Angelo Toselli, Pietro di Gottardo Gonzago) and classicist architects (Francesco Galli Bibiena, G. B. Piranesi, Jean François Thomas de Thomon), as well as sketches of Soviet architects, performed in the framework of competitive projects (Ivan Aleksandrovich Fomin, Boris Mikhailovich lofan, Arkady Grigoryevich Mordvinov, Lev Vladimirovich Rudnev and others) (Figure 3), we had a chance to carry out a comparative analysis of exhibited sketches and compare them with other published works in other editions.

We were looking for an answer to the question whether there were common visually apparent signs of a single compositional language in Piranesi's prints (of high artistic value and those considered to be less expressive, i.e. orthographic and axonometric projections)? We suppose that his system of architectural graphics may have been found and caught up by his followers, classicist artists and artists of the Soviet period. Did they use the same hornbook of "spatial constructions"? We borrowed this concept from the work of $B$. V. Rauschenbach (1975) to emphasize the meaning of the perspective as a means of the composition.

In order to reveal hidden compositional patterns in graphics, we took a sketch by G. Valeriani (Figure 4) presented at the exhibition and compared it with a reproduction of a sketch of a design scenery for the opera "Scipione" represented in the work of M. $\mathrm{S}$. Konopleva "Scene painter Giuseppe Valeriani" (1948).

It should be noted that G. B. Piranesi "worked with stage designers from Rome, brothers Domenico and Giuseppe Valeriani" (Sorokina, 2007), the apprentices of Venetian Marco Ricci (the master of Capriccio, who also painted fictional landscapes with ancient Roman ruins and stage scenery). According to researcher N. I. Sorokina, Piranesi "conceived the style" of Ricci through this acquaintance (Sorokina, 2007).

When comparing two sketches of Marco Ricci and G. Valeriani, it can be seen that both are performed in the system of angular perspective, which then was so skillfully mastered by G. B. Piranesi. Drawings of the mentioned artists have the same compositional pattern. Since there is no data on the further development of Marco Ricci's sketches, we undertook a compositional analysis of G. Valeriani's works (Figure 4).

The first sketch of G. Valeriani is different from the project scenery in relation to its geometry: it has a square shape, while the other is rectangular. The stage painter captured all the elements of his future composition on the sketch and then aligned visually, plastically and constructively all these parts on the draft, forming a coherent structure (Fig. 4). Later, G. B. Piranesi learned these lessons of composition and interpreted those compositional techniques artistically in the series "Carceri".

Let us return to the analysis of the exposition. The following stand excited our interest in the central zone of hall No. 30. The fact is that Piranesi headed a restoration workshop and sales of antiques. Piranesi recreated objects of Roman utensils in his engravings on the basis of small original fragments.

The first Piranesi's workshop was situated "on Via del Corso close to the French Academy" (Sorokina, 2007), and the second workshop was "on Via Sistina" (Sorokina, 2007). As we know, the French Academy was housed in the Mancini palace (Italian: Palazzo Mancini) in Rome in the period from 1737 to 1793.

"Students of the French Academy often worked with Piranesi" (Sorokina, 2007) and adopted his technique of "split-second method of drawing", i.e. "grasping of the main idea, colored by emotions and life clear of stiffness and vanity" (Sorokina, 2007). A very small number of Piranesi's sketches preserved, as he had the following opinion (according to J.G. Legrand): "if my drawing is complete, then my engraving would be nothing more than a copy, while on the contrary, I draw my immediate impressions on 
a)

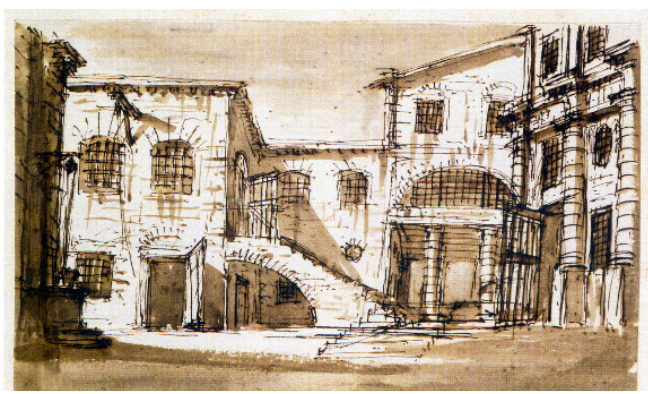

c)

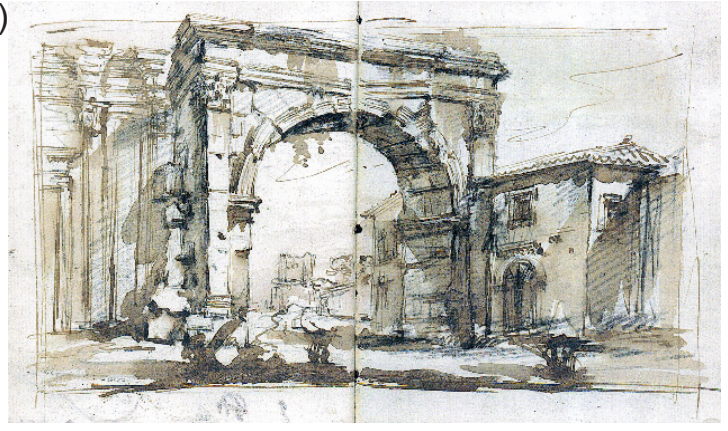

b)

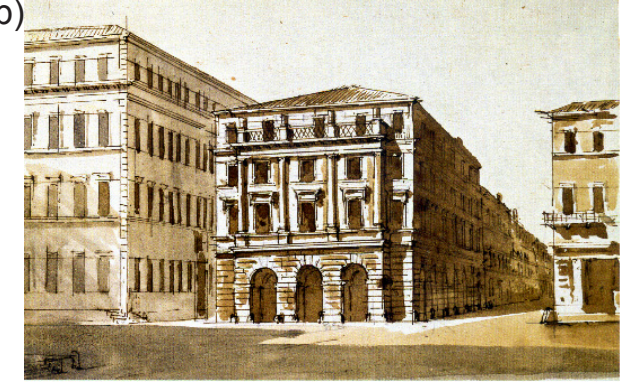

d)

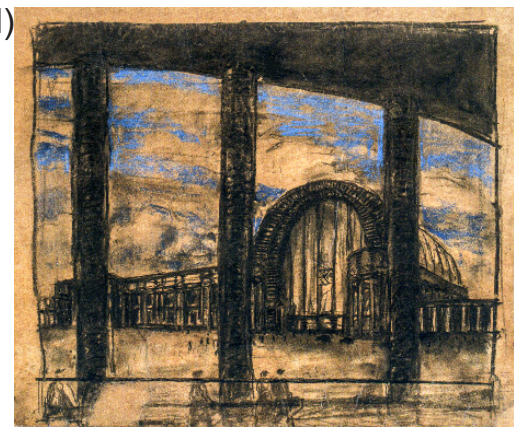

e)

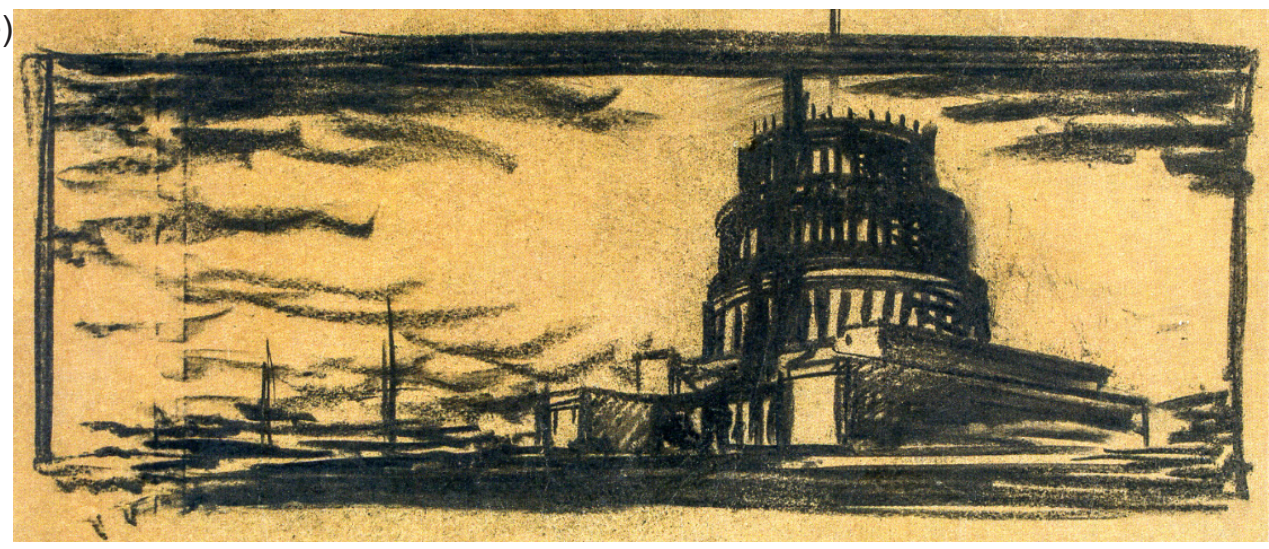

Figure 3. Sketches of scene artists and architects presented at the exhibition "Piranesi. Before and After. Italy-Russia. XVIII-XXI Centuries" and in the catalogue: a) G. Valeriani. The courtyard of the prison. 1740s. Pen, brush, bister, ink, 147x241. Pushkin State Museum of Fine Arts, Moscow; b) Pietro di Gottardo Gonzago. View of the city square and streets. Blue paper, pen, brush, bister, ink, watercolors, pencil. 181x271. Pushkin State Museum of Fine Arts, Moscow; c) G. B. Piranesi. The Arch of Gallienus in Rome. 1740s. Watercolors, pen, ink, pencil. Estense University Library, Modena; d) I. A. Fomin, The building of the Kursk railway station. The perspective through a colonnade of roundabout galleries. Competitive project. 1933. Tracing paper, pencil, charcoal, pastel. 43.5x53.5. Shchusev State Museum of Architecture, Moscow; e) B. M. lofan. Sketch adopted as the basis for the project of the Palace of the Soviets in Moscow. Perspective. 1933. Version. Tracing paper, charcoal, lacquer, 39.4x70.3. Shchusev State Museum of Architecture, Moscow

a copper sheet, creating an original work" (Sorokina, 2007).

What did Piranesi mean with "immediate impression"? As we know, the technology of etching transfer on the plate is carried out with a tracing paper. The main line and outlines are transferred on the plate. Then, linear outlines and the shape are specified.

Before we start to examine the compositions of Piranesi's engravings in the series "Antique Vases, Candelabra, Tombstones, Tomb-Chests, Trivets, Braziers, and Ancient Carvings..." published in 1778, we would like to give a short review of the articles on the subject. Some researches focus on the issue of the historical background of the origin of the engravings and their spatial composition (N.I. Sorokina (2005), Yu. Maiskaya (Rossi, 2016), P. Panza (2013), W. Rieder (1975)). The other group of researches prefers to describe the copies of the original works or the series sheets (e.g. T. Il'ina) (Rossi, 2016), or consider the series of engravings as the basis for material art or jewellery (Lowe, 2011; Wees, 2007; D. Udy, 1978).

Fig. 5 gives a comparative analysis of the composition of the engraving "The staircase with trophies", Sheet VIII, State V, the series "Carceri" (1749) (Sorokina, 2005), and its comparison with the sketch "Interior of an imaginary prison with trophies" 

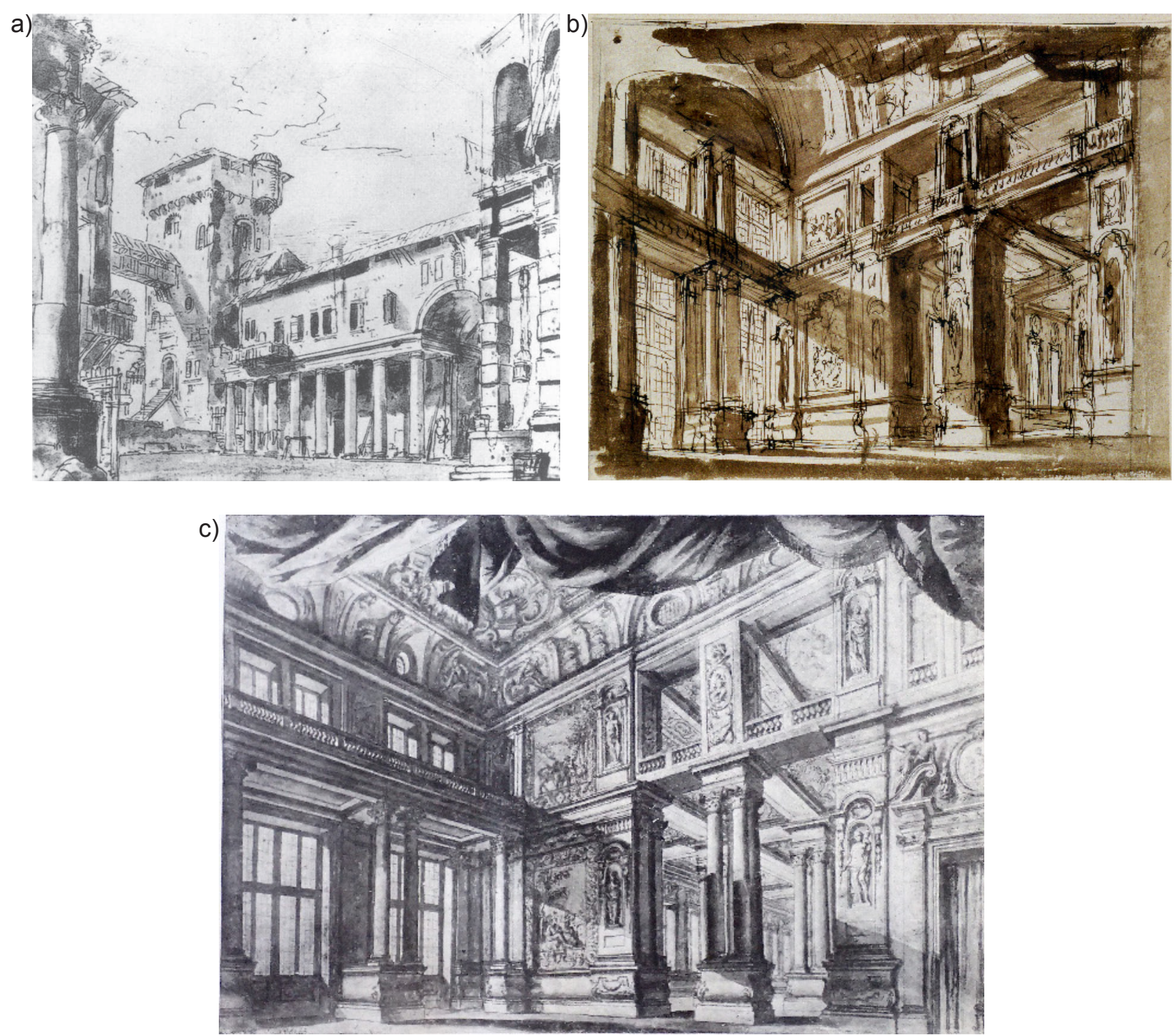

Figure 4. Angular perspective in graphics of Marco Ricci and G. Valeriani. From a sketch to a draft version of the scenery: a) Marco Ricci. The courtyard of an imaginary palace. Drawing, the first half of the XVIII century, Royal Collection, Windsor Castle, Windsor, England; b) G. Valeriani. The interior of the palace hall. Pen, brush, bister, traces of pencil. 170x208, around 1745. Pushkin State Museum of Fine Arts, Moscow; c) G. Valeriani. Draft decoration of the opera "Scipione", State Hermitage, St. Petersburg (Konopleva, 1948)

(1740) (Ippolitov et al., 2011). We revealed a contrast change of plastic composition of the engraving according to its different states. G. Piranesi changed the initial plastic hierarchy of the spots on the plane, thus looking for the ways to capture his "immediate impression", which we understand as spatial view of the represented object. The engraving shows a compositional consistency of the depicted objects on the spots, which can be observed on the first sketch and the first state of the engraving. Further the configuration of elements and their "spatial alignment on the drawing" (the term by B. V. Rauschenbach) are adjusted. Their compositional hierarchy changes (Figure 5). An in-depth space movement starting from the image plane boundaries (layout) prevails on the sketch and the first engraving of State I, while opposite movement out of depth can be observed on the engraving of State $\mathrm{V}$. The latter engraving comprises a dynamic equilibrium of both forces, which helps the viewer to form a complete image of a closed architectural space and visual movement during viewing of the engraving. The artist leads the viewer's glance by means of the composition arranged according to the "labyrinth" principle, when one gets at one and the same point of the compositional center of the engraving, no matter where one's glance is wandering.

As we know, in architecture, "the compositional center is correlated with the main parts, based on rhythmic order and contrasting oppositions. Identification of the compositional center is provided with intergrowth of intensity of one or a group of properties and their maximum intensity in the predominant part of the architecture" (Ikonnikov, 
a)

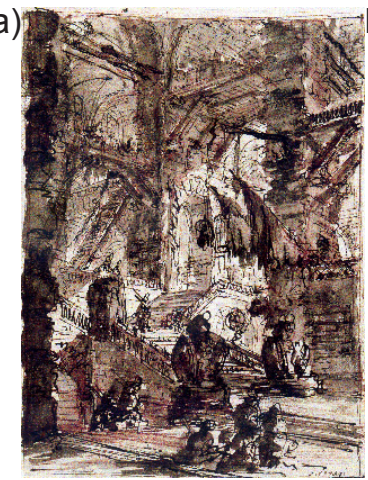

e)

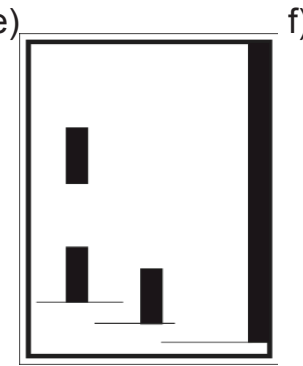

f)
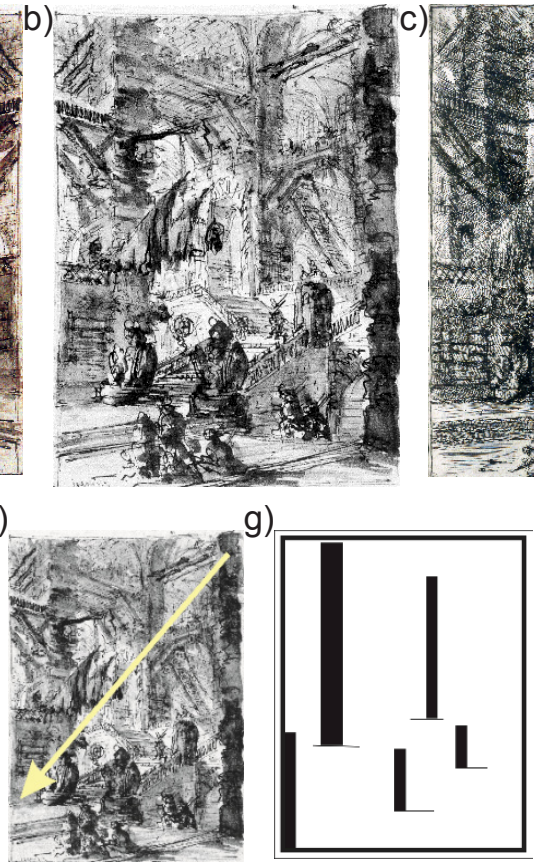

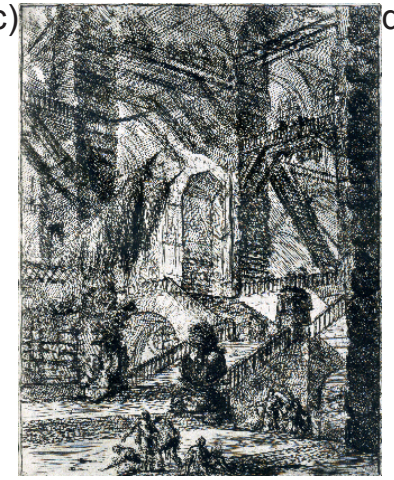

h)

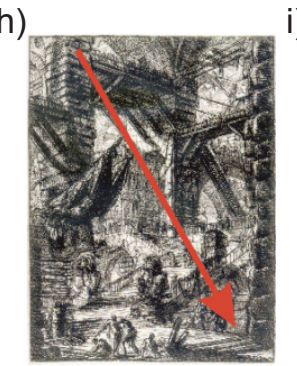

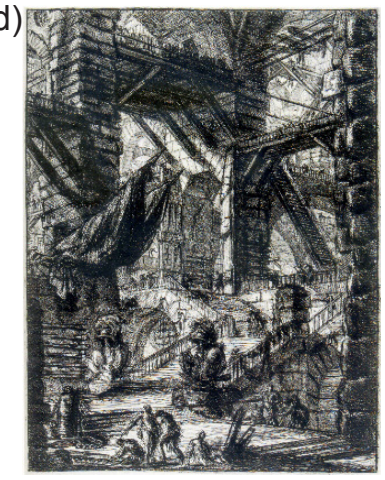

i)

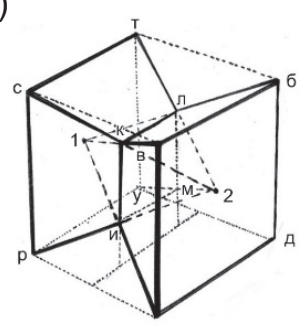

Figure 5. Series "Carceri" (1749): a) G. B. Piranesi. Interior of an imaginary prison with trophies. Pen and brush of brown tones, red chalk. 1740s. Kunsthalle, Hamburg; b) mirrored G. B. Piranesi's sketch performed in Corel Photo-Paint; c) The staircase with trophies. Sheet VIII. Etching with chisel, 561x415. State I. State Hermitage, St. Petersburg; d) The staircase with trophies. Sheet VIII. Etching, chisel, 550x405. State V. Pushkin State Museum of Fine Arts, Moscow; e) a pattern of distribution of black spots on a sketch and engraving of State I; f) direction of the engraving space in-depth created by spots; g) a pattern of distribution of black spots on an engraving of State $\mathrm{V} ; \mathrm{h}$ ) direction out of depth of the engraving space created by spots; i) a cubic model reflecting the principle of spatial constructions of the plastic arrangement of spots in the plane, revealing a compositional and spatial thinking of G. B. Piranesi

2001). For the purposes of the analysis of the composition of the engravings included in the series "Antique Vases, Candelabra, Tombstones, TombChests, Trivets, Braziers, and Ancient Carvings...", let us determine the compositional center as a part of the image (element, area, object, or space) which geometric, rhythmic, sculptural, and qualitative features contrast with its environment. It prevails over other parts in structural hierarchy of compositional elements. An image may show several centers, according to focus of our analysis, i.e. form, space, or plane, which may result in revealing the objective, spatial, and planar centers. Their correlation indicates the final position of the compositional center. The following types of spot contrasting are used for visual detection of the Piranesi's engraving center: lightness, orientation, size, etc. The text on the image also accentuates the plane and focuses the viewer's attention on the main center.

It should be noted, that not all reproductions contain the explanative text on Piranesi's engravings, though such text is essential for compositional integrity of the image. For example, reproduction published in 1905 (Vincent, 1905) contains either a part of the text or no text at all. The album published in 2000 shows the full text (see Figure 6).

Hall No. 30 held Piranesi's architectural graphics, the series "Antique Vases, Candelabra..."
We revealed certain logic of compositional arrangement of the works due to the order of their hanging.

On the one hand, while the drawing method (parallel projection onto the plane) remains within the conventional system of shape arrangement, the graphics is not divided into two parts, "technical" (drawing, sketch, demonstration drawing with pattern entities) and "artistic" (image) (Ikonnikov, 2001), remaining a single unit, where one part amplifies "ideological and artistic side" of the work, and the idea of the artist (Rauschenbach, 1975).

We changed the sequence of sheets of the $G$. B. Piranesi's series "Antique Vases and Candelabra" to reveal hidden internal compositional logic of their arrangement.

For graphic recreation of antique objects, he used angular and front perspectives. Previously, angular perspective was widely used by stage painters and accomplished with the help of orthogonal projections of the plane and the face of the perspective view of the interior. Stage painter Ferdinando Galli Bibiena described the method of its construction in his treatise (1711) (Figure 6).

Architectural graphics, "technical drawings" by Piranesi are not two-dimensional, but threedimensional $(x, y, z)$. The compositional center is located on the axis, the base of which is fixed on the 
a)

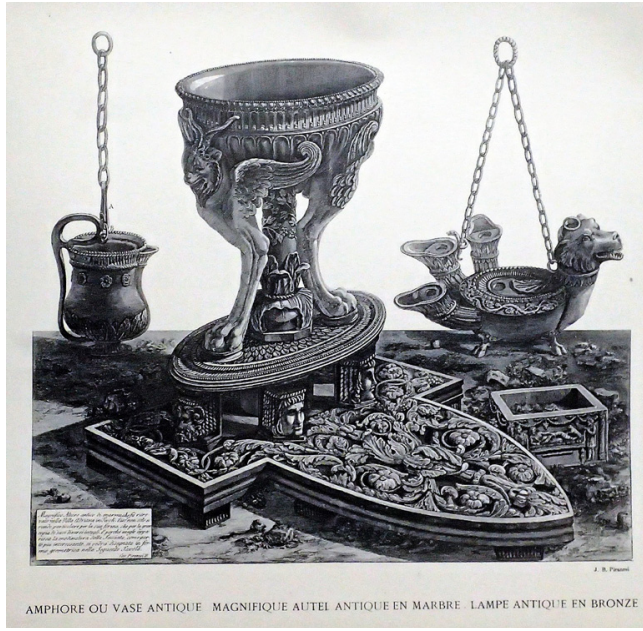

b)

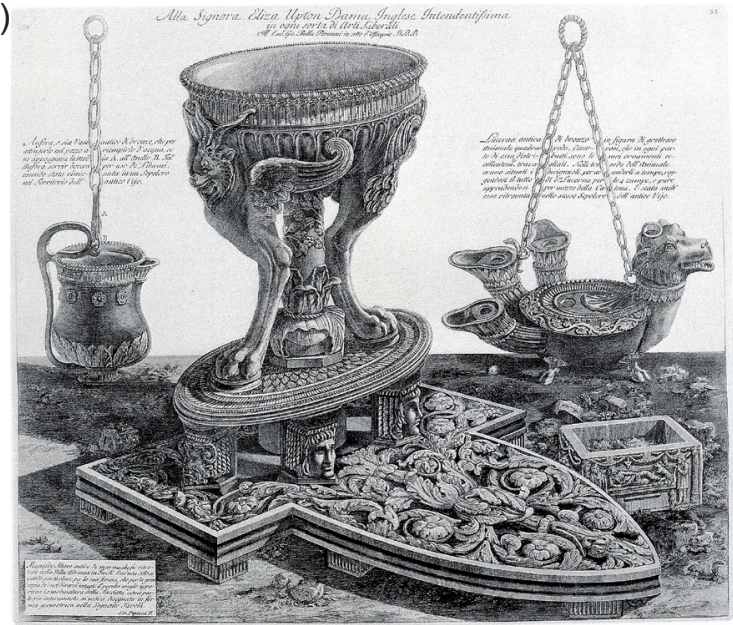

Figure 6. On compositional integrity of the engravings: a) reproduction of Piranesi's vase ("Amphore ou vase antique en bronze") published in 1905 (Piranesi J.-B. Vases, candelabres sarcophacges, trepieds lampes et ornements divers: reproduction de l'edition originale. - Paris: Auguste Vincent, editeur, 1905). SPSUACE Main Library; b) reproduction of "Amphore ou vase antique en bronze" published in 2000 (text preserved) (Ficacci L., Giovanni Battista Piranesi: The compl. etchings / Luigi Ficacci. - Köln etc : Taschen, cop. 2000. - 799 c.)

intersection of diagonal directions in the cubic space of the engraving (Figure $8 \mathrm{e}, \mathrm{f}, \mathrm{h}, \mathrm{i}$ ).

Figure 8 shows different compositions on the sheets of the series "Vases..." The compositional center is moved above the geometric center on one works and below the geometric center on other works. The artist uses compositions with two or three centers, when single compositional center splits to sub-centers. As we know, two intersecting diagonal lines starting from the boundaries of the engraving reveal its geometric center; two intersecting directions in space may also indicate the spatial center. The author indicates the start point of "indepth diagonal movement" (term of art), which starts from the boundaries, by means of the plane marked by the explanatory inscriptions.

Piranesi applies a range of techniques to induce spatial perception of the depicted objects. The first compositional technique is based on the contrast between the shape of the object and plane background, which is intensified by the explanatory inscriptions. The compositional center coincides with the geometric center (see Figure $8 \mathrm{a}, \mathrm{b}$ ). a)

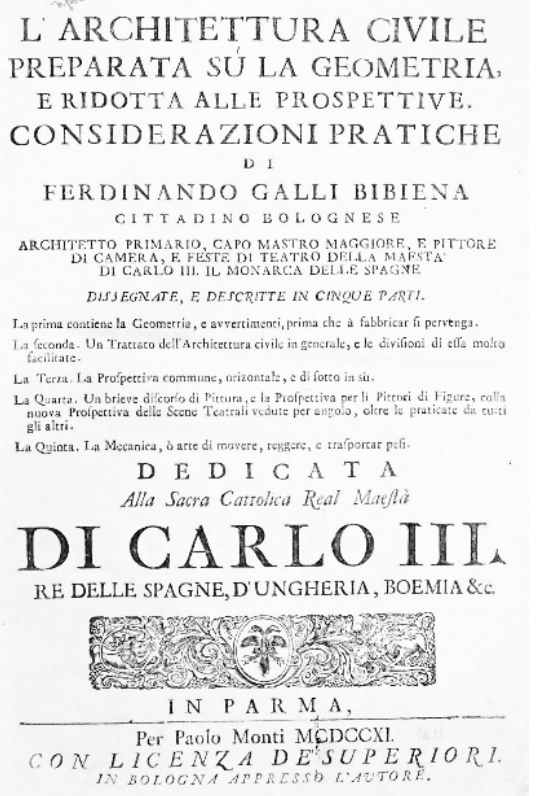

b)

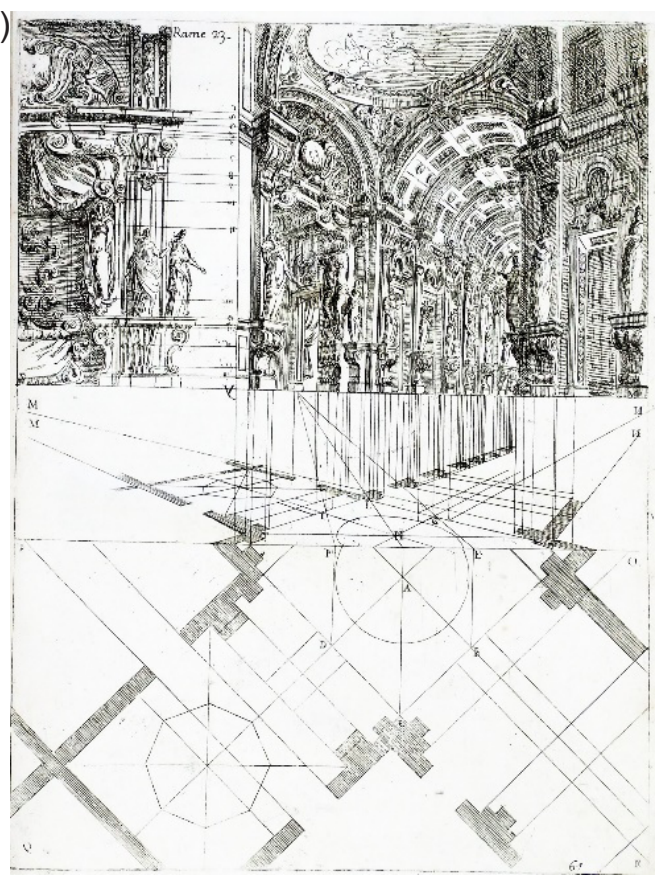

Figure 7. Ferdinando Galli Bibiena's treatise (1711) stored in the SPSUACE Main Library, Saint Petersburg: a) the title page; b) angular perspective through the example of the interior 
a)

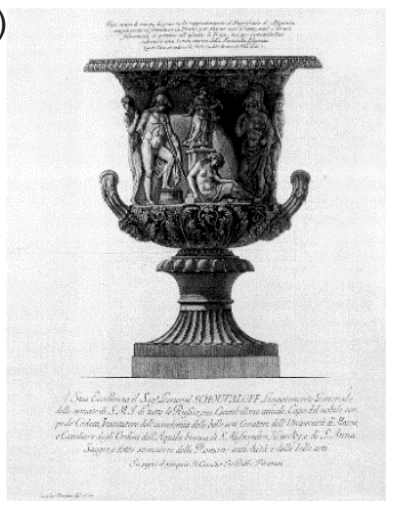

e)

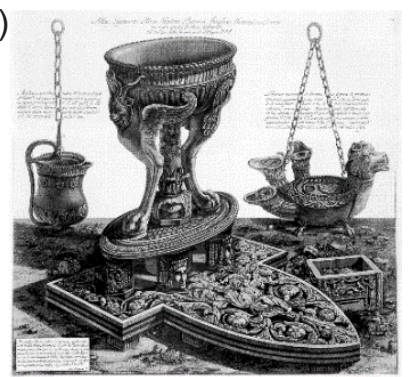

b)

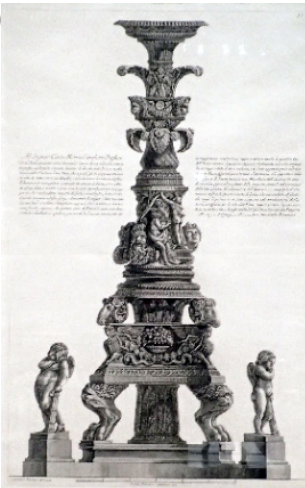

f)

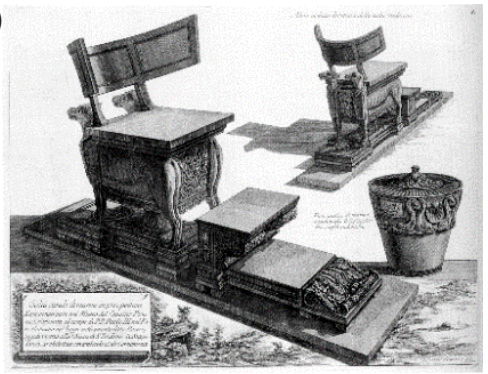

c)

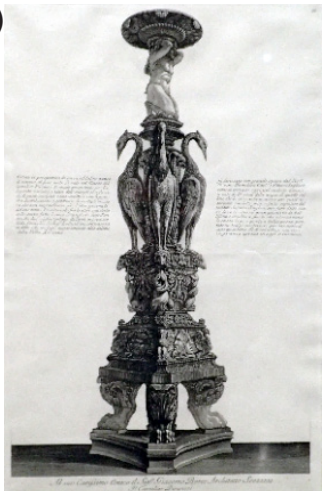

d)

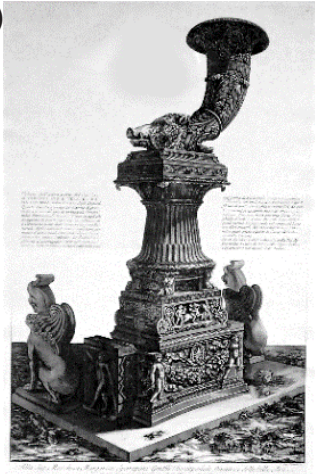

g)

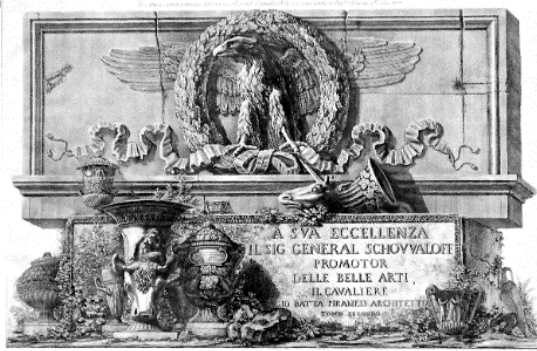

h)
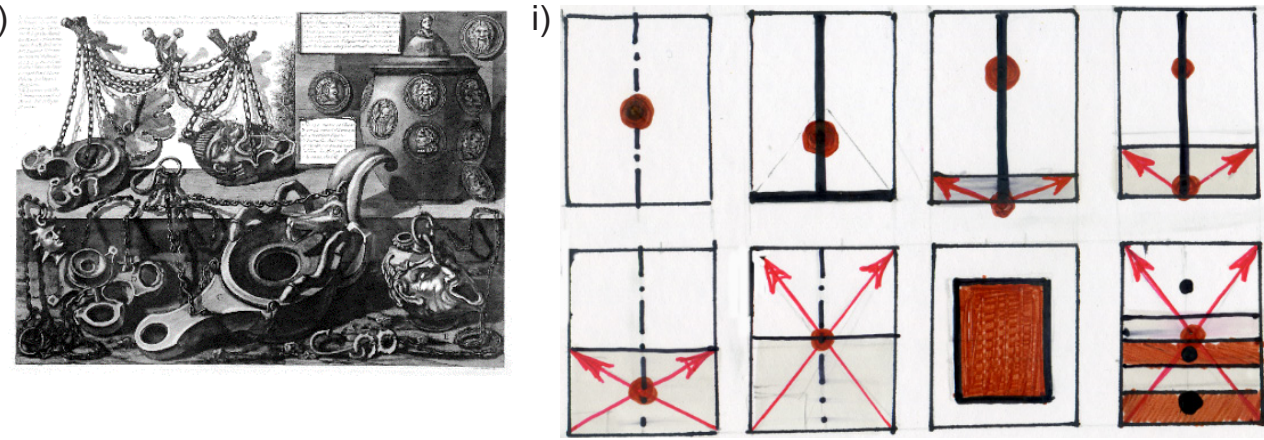

j)

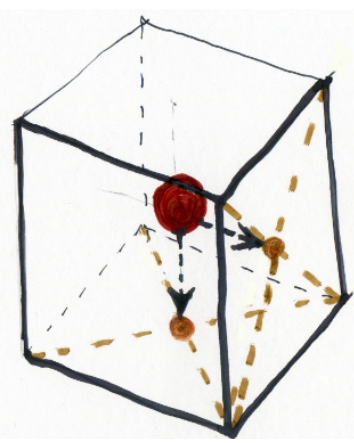

k)

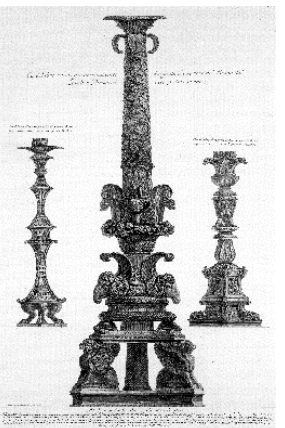

\begin{abstract}
I)
\end{abstract}

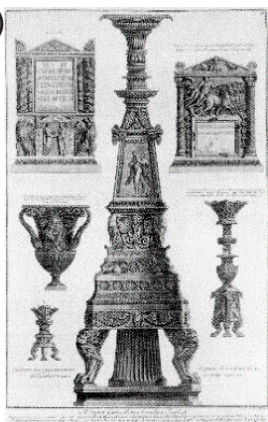

m)

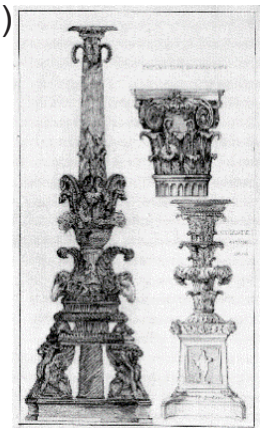

Figure 8. The hornbook of spatial constructions of composition in the plane through the example of the series of engravings "Antique Vases, Candelabra..." by G. B. Piranesi (Pushkin State Museum of Fine Arts, Moscow) (Sorokina, 2005).

The basic principles of the first stage of composition (work with the compositional center):

a) marble vase with a scene of Iphigenia sacrifice. Etching, chisel, 530x390. Engraved by Piranesi;

b) candelabrum from the Palazzo Salviati (Piranesi's candelabrum), 655x410. Engraved by Piranesi;

c) perspective view of a large marble candelabrum found at Hadrian's Villa in Tivoli. Etching, chisel, $663 \times 415$.

Engraved by Piranesi;

d) funerary monument completed with a rhyton with a boar head. Etching, chisel, 670x420. Engraved by Piranesi;

e) ancient marble altar, bronze lamp and vase. 448x495. Engraved by Piranesi;

f) curule seat and marble vase. Etching, chisel, 385x530. Engraved by Piranesi;

g) various lamps and a vase encrusted with cameos. 388x535. Engraved by Piranesi;

h) the title page of the second volume of the series with ancient relief of the portico of the Santi Apostoli church in Rome. Etching, chisel, 480x715. Engraved by Piranesi;

i) three candelabra. Etching, chisel, 685x435. Engraved by Piranesi

j) projection of a form in the geometric center on orthogonal planes;

k) three candelabra, a vase and two funeral urns. Etching, chisel, $675 \times 432$. Engraved by Piranesi;

l) three candelabra, a vase and two funeral urns. Etching, chisel, $675 \times 432$;

$\mathrm{m}$ ) in future, this combination of imaging would be continued in the academic work of student architect N. D. Kolli

"Academic work "Ancient Rome". Paper, pencil, ink. 
The second technique comprises formation of image depth by means of angular perspective. In this case, G. Piranesi uses alternation of angular and frontal planes for finding their equilibrium. The compositional equilibrium axis is fixed by intersecting diagonal directions formed by the planes of the objects depicted. The compositional center is displaced rightwards from the geometric center (see Figure $8 \mathrm{c}, \mathrm{d}, \mathrm{e}, \mathrm{f}$ ).

The third technique is formation of space depth by means alternation of orthogonal projections. The projections in this case vary in their spots dimensional characteristics and include the elements similar in certain parameters. Such compositional technique ("scale leap") implies scaling of a spot on a second ground and helps to create an illusion of depth on a plane (see Fig. 8 k, I, m).

The fourth technique is to emphasize a frontal perspective. The compositional center is scattered between several sub-centers which form the area of the main compositional center of the picture see Figure $8 \mathrm{i}$ ).

As we know, G. B. Piranesi's series of engravings "Antique Vases, Candelabra..." had been published since 1768 ("since 1768, the beginning of publishing of individual engravings of ancient monuments of applied art") (Sorokina, 2005). This information, as well as the comparative analysis of the part of the series sheets, allows us to declare that the architect affirmed a hornbook of compositional techniques of his spatial constructions, which he had previously tried in the series "Raccolta di varie vedute di Romma..." (Collection of Various Views of Rome...) (1752). Here the composition is formed by means of blending and synthesis of several structures, different levels, while in "Antique Vases, Candelabra..." it is more visual.

Engravings of the series "Views of Paestum" are exhibited as a part of the exposition located on the Main Staircase. Supervisors of the exhibition accompanied them with photographs made by Gianluca Baronchelli in 2016; these photos illustrate the same point of the landscape viewing in photographs and Piranesi's engravings, which facilitates the disclosure of Piranesi's compositional thinking during their comparison (see Figure 9).

The visual comparative analysis of these engravings and photographs results in detection of multiple viewpoints (arranged along one horizontal axis). J. B. Rapp (2008) also described this phenomenon, though she examined another series of Piranesi's engravings. Applying multiple viewpoints on the engraving, the architect evaded the angle view that we can observe on photographs, where objects out of a "clear vision" change their geometric dimensions (elongate) due to the peculiarities of human visual perception (Rieder, 1975). a)

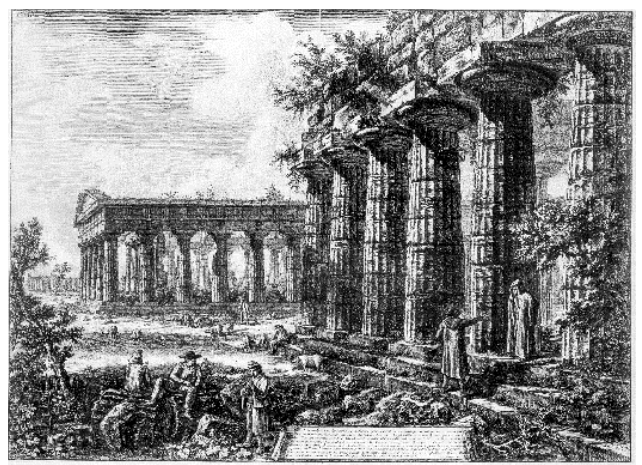

C)

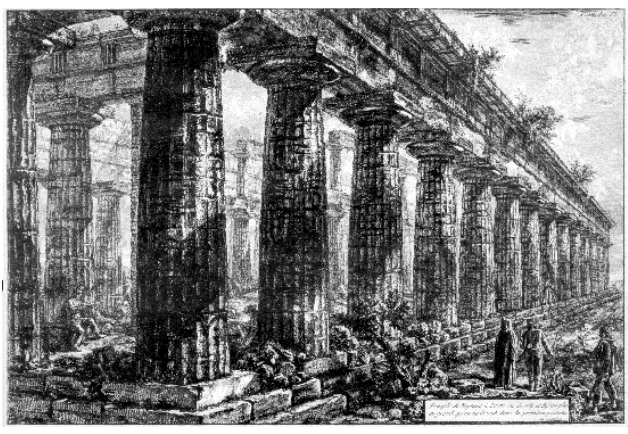

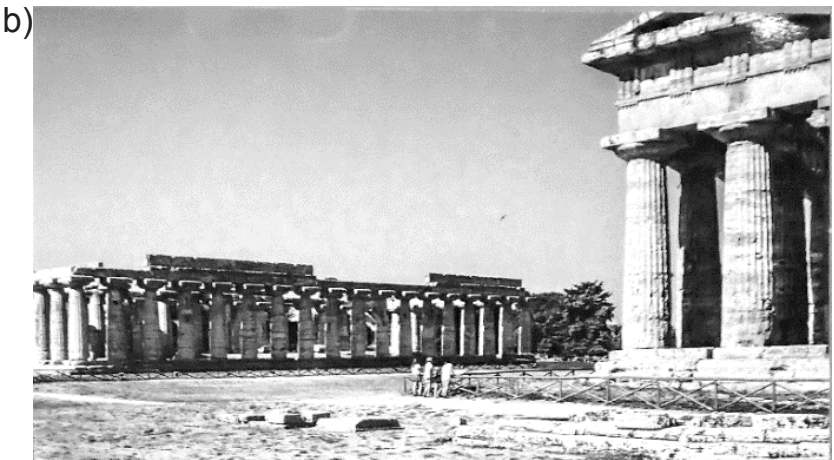

d)
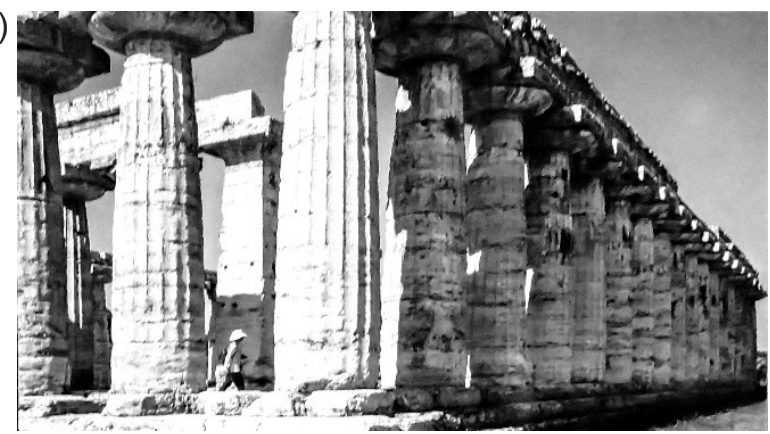

Figure 9. "Piranesi. Before and After. Italy-Russia. XVIII-XXI Centuries". Photos by Gianluca Baronchelli.

Photography as a means of identification of peculiarities of compositional thinking of G. Piranesi and his son F. Piranesi through the example of the series "Views of Paestum": a) G. B. Piranesi. View of the columns at the Basilica facade. Sheet III. Etching, chisel, 502x680. Pushkin State Museum of Fine Arts, Moscow; b) Gianluca Baronchelli. Photograph, 2016; c) G. B. Piranesi. Temple of Neptune. Sheet XI. Etching, chisel, 460x690. Pushkin State Museum of Fine Arts, Moscow; g) Gianluca Baronchelli. Photograph, 2016 


\section{Conclusions}

In his art, G. B. Piranesi developed and affirmed the accumulated experience of his predecessors and teachers, who had used angular perspective as an artistic tool of arrangement on the plane, necessary for architectural and artistic imaging. The artist elaborated the visual scenario of movement both on the plane and inside the space of the engraving. In some cases, he emphasized diagonal structural lines starting from the edges of the engraving, in other cases, applying contrast between vertical and horizontal directions, imparted a psychological tension to his work.

\section{Results}

The first comparative composition analysis of some sheets in series "Antique Vases, Candelabra, Tombstones, Tomb-Chests, Trivets, Braziers, and Ancient Carvings..." revealed a part of Piranesi's hornbook of spatial constructions.

The applied comprehensive analysis of Piranesi's architectural graphics was aimed at revealing the artist's method, which showed his striving for focused and consistent presentation of his artistic conception.

\section{References}

Ikonnikov, A.V. (ed.) (2001). Arkhitektura i gradostroitel'stvo. Entsiklopediya [Architecture and city planning. Encyclopedia]. Moscow: Stroyizdat (in Russian).

Ippolitov, A.V., Korshunova, M.F. and Uspensky V.M. (2011). Ruins, palaces and prisons. Giovanni Battista Piranesi and Italian eighteenth-century architectural fantasies: exhibition catalogue. Saint Petersburg: Publishing House of the State Hermitage.

Konopleva, M.S. (1948). Teatral'nyi zhivopisets Dzhuzeppe Valeriani: Materialy k biografii i istorii tvorchestva [Stage painter Guiseppe Valeriani: materials of biography and the history of his art]. Leningrad: Volodarsky Printing House of the State Hermitage (in Russian).

Lowe, A. (2011). Messing About with Masterpieces: New Work by Giambattista Piranesi (1720-1778). Art in Print, 1(1), pp.14-24.

Panza, P. (2013). Sulla provenienza e il restauro di marmi antichi dal "Museo Piranesi". Saggi e Memorie di Storia dell Arte, 37, pp. 62-75 (in Italian).

Rapp, J.B. (2008). A geometrical analysis of multiple viewpoint perspective in the work of Giovanni Battista Piranesi: an application of geometric restitution of perspective. Journal of Architecture, 13(6), pp. 701-736.

Rauschenbach, B.V. (1975). Prostranstvennye postroeniya v drevnerusskoi zhivopisi [Spatial arrangements in early Russian art]. Moscow: Nauka Publishing House (in Russian).

Rieder, W. (1975). Piranesi at Gorhambury. The Burlington Magazine, 117(870), pp. 582, 584-591.

Rossi, F. (ed.) (2016). Piranesi. Before and After, Italy - Russia, XVIII-XXI centuries: exhibition catalogue. Pushkin State Museum of Fine Arts, September 19 - November 13, 2016. Moscow, Treviso.

Rynin, N.A. (1918). Nachertatel'naya geometriya [Perspective geometry]. Petrograd: Tipografiya Georgievskogo komiteta (in Russian).

Sorokina, N.I. (2005). K voprosu o tvorchestve Piranezi-restavratora [Revisiting the issue of Piranesi's creative work as a restorer]. In Ital'yanskii sbornik [Italian book], Issue 4. Moscow: Pamyatniki istoricheskoi mysli, pp. 246-255.

Sorokina, N.I. (2007). Tvorchestvo Dzh. B. Piranezi v kontekste epokhi prosveshcheniya [G. B. Piranesi's art in the view of the Renaissance]. PhD thesis in Arts. Moscow (in Russian).

Udy, D. (1978). Piranesi's "Vasi”, the English Silversmith and His Patrons. The Burlington Magazine, 120(909), pp. 820-831.

Vincent, A. (ed.) (1905). Piranesi J.-B. Vases, candélabres, sarcophacges, trépieds, lampes et ornements divers: reproduction de l'edition originale. Paris.

Wees, B.C. (2007). Ancient Rome via the Erie Canal: The De Witt Clinton Vases. Metropolitan Museum Journal, 42, pp. 139-162. 